\title{
On the shifting spatial logics of socioeconomic regulation in post-1949 China
}

\author{
Kean Fan Lim \\ School of Geography \\ University of Nottingham \\ Sir Clive Granger Building \\ University Park, \\ Nottingham \\ NG7 2RD, UK \\ Email: keanfan.lim@nottingham.ac.uk
}

7 August 2015

\author{
Forthcoming in Territory, Politics, Governance \\ Pre-publication version
}

\begin{abstract}
This paper argues that new rounds of socioeconomic reforms in post-1949 China, each with their distinct geographical expressions, constitute a complex palimpsest rather than a straightforward process of historical succession. Drawing on a review of extensive empirical evidence, the paper complicates two dichotomous portrayals of socioeconomic 'transition' in China, namely centralization and egalitarianism (the Mao era) and decentralization and uneven development (the postMao era). It demonstrates these binaries cannot adequately explain the post-Mao economic 'miracle' when decentralized governance and uneven development also characterized the Mao era. The paper concludes that decentralized governance and uneven development are not antithetical to the quest for perpetual CPC rule; just as the Mao administration strategically blended centralizing mechanisms with instituted uneven development to consolidate its power, the post-Mao regimes are repurposing Mao-era regulatory techniques to achieve the same objective.
\end{abstract}

Key words: China; regulation; socioeconomic transition; uneven development; decentralization; centralization 


\title{
On the shifting spatial logics of socioeconomic regulation in post-1949 China
}

\begin{abstract}
This paper argues that new rounds of socioeconomic reforms in post-1949 China, each with their distinct geographical expressions, constitute a complex palimpsest rather than a straightforward process of historical succession. Drawing on a review of extensive empirical evidence, the paper complicates two dichotomous portrayals of socioeconomic 'transition' in China, namely centralization and egalitarianism (the Mao era) and decentralization and uneven development (the post-Mao era). It demonstrates these binaries cannot adequately explain the post-Mao economic 'miracle' when decentralized governance and uneven development also characterized the Mao era. The paper concludes that decentralized governance and uneven development are not antithetical to the quest for perpetual CPC rule; just as the Mao administration strategically blended centralizing mechanisms with instituted uneven development to consolidate its power, the post-Mao regimes are repurposing Mao-era regulatory techniques to achieve the same objective.
\end{abstract}

Key words: China; regulation; socioeconomic transition; uneven development; decentralization; centralization

In a society in which the government dominates all spheres of social life, as in China's centrally planned socialist system before 1978 , it is...presumed that social equality would as a matter of course be promoted very systematically... However, whether planners and other bureaucrats adopt and implement policies that foster equality or generate inequality depends on their goals, priorities and perceptions of societal needs...So specifying the role of the socialist state in counteracting or aggravating any particular inequality is an empirical question, not something that can be assumed almost by definition (socialist = equality). Martin King Whyte (2010: 4-5)

Everyone is talking about deepening reforms, but what is to be reformed? What are the problems that reforms in China are addressing? Of course many people are of the opinion that we were a planned economy in the past and right now we have become a market economy, but is it really that simple? - Wen Tiejun, senior economist and long-time consultant to the Communist Party of China (Interview with Nanfang Ribao, 23 June 2013; author's translation)

\section{Introduction}

During a meeting with the Danish Premier, Poul Hartling, in October 1974, the Chairman of the Communist Party of China (CPC), Mao Zedong, observed that approaches to socioeconomic regulation in post-1949 'new China' were "not much different from the old society" (CCCPC Party Literature Research Office, 1998: 413). Shaped by feudalism, warlordism and imperialism, regulatory approaches in the "old society" comprised the wage system; the allocation of rewards according to expended labor power; and the exchange of commodities through fiat money (mainly the fabi and Gold Yuan issued by the Nationalist 
Party and the yen used by Japanese colonialists in Manchuria). At the meeting, Mao highlighted to Hartling an institutional invention he considered definitive of 'new China': the collective ownership of land, labor power and money. ${ }^{1}$ But his juxtaposition of nationalized means of production with quintessentially Marxian categories of 'capitalistic' processes explicitly - if inadvertently - underscored the nature of the CPC's economic role in a socialist $^{2}$ 'new China': to develop a national economic project through the extraction of monetary-defined surplus value from labor power. While much has changed in the three decades that followed the Mao regime, the transposition of the CPC into a more proactive player in the process of capital accumulation arguably gives Mao's observation a contemporary resonance.

The seemingly paradoxical entwinement of state-driven capital accumulation with market-oriented reforms in the post-Mao era is exemplified by the prominence given to the methods of the "old society" during the Third Plenum of the $18^{\text {th }}$ Party Congress. Chaired by the newly-installed Xi Jinping administration in November 2013, the Congress offered to give "decisive" roles to market mechanisms in socioeconomic regulation. Concurrently, however, it pledged to "persist with the dominant role of the public ownership system, give rein to the leading role of the State-owned economy, incessantly strengthen the vitality, strength of control and the influence of the State-owned economy" (Communique of the Third Plenum, published in Xinhua, 12 November 2013; author's translation). This persistence gained a high international profile in the summer of 2015 when the Chinese central government expended an estimated 1 trillion yuan ( US $\$ 161$ billion) on what it terms a "necessary" military-styled intervention to rescue domestic stock markets from a full-blown crisis (Caixin, 16 July 2015; South China Morning Post, 23 July 2015). The strong capacity of the CPC to align market mechanisms to its political objectives (re)opens a theoretically significant question on Chinese politico-economic evolution: what are the connections 
between the economic growth 'miracle' of the past three decades and regulatory logics instituted by the Mao administration?

Research consistently suggests post-Mao politico-economic transition is not a linear movement into a new stage of development. Within the first decade of the 1978 'reform and liberalization' (gaige kaifang), Solinger (1989: 19) presciently noticed how the "most capitalistic of practices have not been sanctioned by the Chinese leadership out of an urge to reorient the economy away from state ownership and toward privatization... The reforms, in the eyes of the politicians, amount to a means of managing the state's macro-finances, while preserving state/public ownership". Undergirding this preservation, Lyons (1991: 471) contends, is the desire to retain control over subnational regions: "Although China's postMao leaders have shown greater concern with efficiency and with the potential trade-offs between efficiency and such goals as balance and equity, their continuation of many redistributive policies indicates they have not abandoned regional objectives" (cf. Li and Wu, 2012; Wei, 2013). More recently, Heilmann and Perry (2010: 10) continue to detect the constitutive importance of inherited legacies: "Moving from the Mao era's 'socialist construction' to the post-Mao era's 'reform and opening', China has not simply jettisoned its revolutionary past as it 'transits' toward a democratic future. Rather, CPC leaders in the post-Mao era have managed to fashion a surprisingly adaptive pattern of authoritarian rule capable so far of withstanding challenges, including grievous and growing social and spatial inequalities, which would surely have undone less robust or flexible regimes". In view of these observations, Wei (2011: 23) is arguably correct in claiming that "China's reform during the post-Mao era was not a complete departure or an absolute separation from the institutions and policies of the Mao era; it is both the continuity and discontinuity with the immediate past and a complex mingling of past legacies with new policy directions."

This paper offers a fresh reading of this "complex mingling" from a geographical perspective. It begins, as its analytical point of departure, with the understanding that space 
and time are not inherently separate conceptual categories. Rather, logics of socioeconomic regulation are layered unevenly and at different moments across Chinese state space. Blending existing social-scientific empirical research with Chinese historical sources, published comments from leading scholars within China and first-hand information from senior planners, the paper develops a critical review that illustrates and complicates two binaries, namely 1) the characterization of a 'centralized' Mao era and decentralized governance as the driver of post-Mao 'reform and liberalization'; and 2) the portrayal of "social and spatial inequalities", to re-borrow Heilmann and Perry's (2011: 10) terms, as outcomes of post-Mao governance vis-à-vis more egalitarian developmental strategies under the Mao administration. Political centralization in the late 1950s - primarily instituted through the 'scaling up' of household-based landownership to the communes and the state, the rural collectivization of economic production and the strict control of demographic mobility - was actually premised on decentralization and instituted uneven development. In addition, urban-rural inequality peaked during the 1958-1960 Great Leap Forward in the history of 'new China', while inter-provincial disparities were pronounced throughout the Mao era. These reviews collectively suggest new rounds of socioeconomic reforms in post1949 'new China', each with their distinct geographical expressions, constitute a complex palimpsest rather than a straightforward process of historical succession.

The discussion is organized in three parts. Section 2 will problematize the view of politico-economic development in China as outcomes of centralization or decentralization. Section 3 presents an evaluation of empirical data on uneven development during and after the Mao era. These sections seek jointly to illustrate how static conceptions of space and time preclude a more fluid theorization of Chinese economic growth since 1978, specifically how inherited institutions interact with reformist initiatives to enhance developmental goals, primarily state-driven capital accumulation. The paper then concludes by considering how decentralized governance and uneven development are not antitheses of CPC rule; just as 
the Mao administration strategically blended centralizing mechanisms with instituted uneven development to consolidate its power, the post-Mao regimes are repurposing Mao-era regulatory techniques to achieve the same objective.

\section{The centralization-decentralization binary: contributions and constraints}

The rapid economic growth in post-Mao China is widely construed as driven by decentralized local governments. 'Local' (difang) is broadly used in China with reference to administrative levels that are not 'central' (zhongyang), namely the provincial, subprovincial, prefecture, county, etc. "Whereas the central state set the reform process in motion and provided localities with the incentives and the leeway to develop economically", writes Oi (1992: 101), "it is local government that has determined the outcome of reform in China." Montinola et al (1995) view post-Mao reforms as characteristic of a form of "marketpreserving federalism", a strong claim at the time and even today given the unitary political system that emphasizes absolute power in the central government (cf. Shirk, 1993; Huang, 1996; Lawrence and Martin, 2013). To Qian and Roland (1998: 1156), "one of the most distinct features of China's transition has been associated with devolution of authority from the central to local levels of government". This observation builds on an earlier claim by Qian and Weingast (1995: 13) that the "critical component of China's market-oriented reform, which began in 1979 , is decentralization".

Decentralized regulation in the post-Mao era is broadly defined as a three-pronged process. It comprises 1) new policymaking autonomy given to local governments; 2) new fiscal responsibilities to finance new socioeconomic projects that were either previously undertaken by the central government or were engendered by new 'supply-side' socioeconomic policies; and 3) direct responses by local governments to the competitive pressures generated by economic integration into the global system of capitalism (see, inter alia, Liu, 1992; Chung, 2000; Su and Yang, 2000; Remick, 2002; He and Wu, 2009; Tsing, 
2010). The common approach in these works is the attribution of the post-1978 economic growth 'miracle' to the decentralization of regulatory capacities to city-regions. In other words, there is a positive causal relationship between decentralized governance and rapid economic growth.

These empirical accounts have illuminated our understanding of the fast-changing Chinese political economy in two major ways. First, they demonstrate cogently how the Chinese central government does not - or, indeed, cannot - function as an omnipotent and omnipresent allocative-cum-redistributive institution. This is because of the inherent difficulty for central planning agencies to gain timely access to information on demand and supply across what has always been a geographically-expansive and socially heterogeneous economy. Indeed, centralized control during the Mao-era existed only under strict control of personal freedoms (Greenhalgh and Winkler, 2005; Dikötter, 2011; Yang, 2012). And even so, commodity supply never prioritized swift responses to (domestic) consumer demand. Second, the proactive approach to reconfigure Chinese state space in relation to the demands of economic liberalization underscores the territory-based politics intrinsic in central governance (cf. Howell, 2006; Wei, 2007; Peck and Zhang, 2013). This is exemplified through the Deng administration's strategy to cater to the interests of provincial officials - or 'playing to the provinces' - in order to develop potent counterweights against senior conservatives in Beijing (Shirk, 1993) ${ }^{3}$. Underpinning this approach was a centralizing logic: the reformers could retain the structure of the Maoist state and facilitate a smoother transition to market-like rule through sharing greater power and benefits (fangquan rangli).

Studies have shown how increased autonomy in provincial decision-making unleashed GDP growth through stretching centrally-defined parameters. Segal and Thun (2001) found centrally-instituted economic policies often encounter re-interpretations and/or resistances at the subnational scales. Wedemen (2001) similarly explains how the 
institutional structure of the CPC encourages "strategic disobedience" at local levels. This dynamic response by local governments triggered observations of the rise of - or a return to - 'mountain-stronghold mentalities' (shantou zhuyi) or 'economic feudalism' (jingji zhuhou). Oi (1992: 126), for instance, predicts "the success of local state corporatism may in the long run force the emergence of something akin to a federal system that more clearly recognizes the rights and power of localities" (see also Oi, 1998). While a federal system did not emerge, localities went on to expand their "rights and power" to drive growth projects. "During the implementation of the central government's macro adjustment policies (hongguan tiaokong)", reflects Han Baojiang of the Party School of the Central Committee of the CPC:

An 'excited phenomenon' amongst local governments, which shouldn't have occurred, became apparent: orders were disobeyed and prohibitions defied (lingbuxing, jinbuzhi), there was no adherence to the adjustment discipline, acceptance of orders were only superficial (yangfengyinwei)...People were even joking that, during the course of regional development in China, a weird phenomenon has occurred: the more a local government covertly disagrees with the central government's macro adjustment policies and behaves more opportunistically, the more the local economy benefits; vice versa. (Interview with China Economic Weekly, 2006; author's translation).

Han's observation corresponds with empirical research that portrays growing tensions within central-local dynamics. Local transgressions against macro-level policies are evident in at least three domains where the central government tried to exert more control, namely to reduce 1) investments in pollutive industries (Economy, 2011; Lan et al, 2012); 2) clandestine financial transactions through the 'shadow banking system' (Tsai, 2004; Li and Hsu, 2012; Breslin, 2014); and 3) speculative investments in real estate (Huang and Yang, 1996, Guo and Huang, 2010). Emergent debates over the superiority of regional developmental approaches further suggests bottom-up constraints on national economic integration have (re)surfaced (Qiu, 2011; Qu, 2012; Zhang and Peck, 2014; ref. discussion on local protectionism in section 3 ). Vis-à-vis the recent injunctions ${ }^{4}$ by the central government to reduce GDP growth targets and correspondingly rein in the powers of prefecture- and county-level urban governments, recurring claims of positive correlations 
between subnational regulatory autonomy and post-Mao GDP growth are certainly not without credence.

A series of historically-engaged reflections paint a more fine-shaded picture of decentralization, however. As Li and Wu (2012: 92) put it, "decentralization is a state strategy", and Wu Jinglian, a senior economic consultant to the CPC, offers a vivid recollection of how this "state strategy" was, in a contradictory twist, already entrenched in the two decades prior to the 1978 reforms:

Following the decentralization of administrative power in 1958 and 1970, chaotic scenes emerged in the economy. Where did the problem come from? Those decentralizing initiatives were implemented within the framework of a 'commandeering economy'. While the microeconomic decisions in enterprises remained totally subject to hierarchical control, dayto-day regulatory power was decentralized. Apart from defense industries and some industries of an experimental nature, all enterprises experienced decentralization to very low levels. From production planning, fixed capital investment, redistribution of goods and capital, financial and fiscal management, credit provision, all processes were decentralized. The outcome was a plethora of 'centers', every local government sought not to fall behind by comparing and amending planning targets, [as such] the targets kept increasing, all sorts of 'satellites' [the nickname of the time for ambitious targets, termed after the Soviet launch of the Sputnik satellite that Mao strongly admired] were released this way. ( $\mathrm{Wu}$, in $\mathrm{Wu}$ and $\mathrm{Ma}$, 2012: 49; author's translation)

Within this "commandeering economy" (mingling jingji), orders were issued randomly without much prior expert knowledge or relation to the national 'plan'. Such randomness termed 'wanton guidance' or xia zhihui - was particularly pronounced during the Great Leap Forward and the Cultural Revolution and contrasted the scientific rationality that enabled the Soviet Union to determine the production and exchange of a vast range of commodities (Qin, 2004: 77-78). The outcome of 'irrational' commandeering was social chaos, widespread poverty in the rural hinterland and entrenched uneven development across the country. For this reason, Wen Tiejun, another senior economist and long-time consultant to the CPC, offers a thought-provoking contention that the Mao era could not even be reduced to the umbrella concept of a "planned economy" (jihua jingji) (ref. Qin, 2004; Qin and Jin, 2012):

If you seriously conduct a little research on contemporary economic history, you will discover before the reforms in 1980 China did not even get to launch a planned economy, or there 
was never an attempt to implement a planned economy in the true sense of its meaning. For us to come up with what resembled a plan and then make the plan reality, this only occurred after the Cultural Revolution, after the chaos was alleviated. It was only from the 1980s that China had the conditions to devise a plan, to implement a plan, what came before could be considered a wartime economy, those were exceptional circumstances and could not count as a planned economy. (Wen Tiejun, 23 Jun 2013, Nanfang Ribao; author's translation)

If Wen is correct, this 'irrational' regulatory logic enabled the CPC to consolidate its control over the newly-formed political economy through a systematic reconfiguration of the means and social relations of production. Private capitalists and the 'landlord and gentry tyrants' (tuhao lieshen) were exterminated in the process, their assets transferred in turn to large state-owned enterprises (SOEs) and/or rural collectives. To understand how this was possible, it would be necessary to discern the role - or, in Whyte's (2010) terms, the primary intentions - of the socialist state under Mao.

During its first decade of power, the Mao government wanted to construct a socialist economy modeled after a Stalin-styled Soviet Union (Li, 2006; Bernstein and Li, 2010). The antithesis to this objective process was individual production (dangan), a lethal capitalistic seed that had no room in Mao's ultimate vision of Chinese socialism. To actualize this vision, the decentralization of 1958 occurred simultaneously with the enhancement of centralized CPC control over bureaucratic functions. Political power was concentrated in the Party Committee, which was then funneled upwards to the General Secretary (the most powerful position in the CPC technically). In an agenda published in January 1958 termed "60 Working Principles", Mao Zedong proclaimed "major power would be monopolized, minor authority decentralized; the Party Committee would decide, everyone else acts" (daquan dulan, xiaoquan fensan; dangwei jueding, gefang quban) (Mao, 1999: 345; author's translation). What followed in June 1958 was the establishment of five bodies overseeing finance, legislation, foreign affairs, science and culture. Mao made it clear in an accompanying directive that

These agencies all belong to the central party and are directly under the purview of the Politburo (zhengzhijü) and the Secretariat (mishuchu). The overall political agenda will be set by the Politburo, the specific implementation by the Party Secretariat. There is only one 
political design arena, not two. Both agenda setting and implementation are integrated, there is no distinction between party and politics. (Mao, 1992: 268; author's translation)

With this injunction, the CPC effectively hollowed out the State Council. The state apparatus of 'new China', technically an independent structure, was subsumed under the party apparatus to become a party-state. This meant the state bureaucracy became a subservient function of party calculations and interests, a phenomenon that persists in the present across literally all socioeconomic spheres despite subsequent rounds of reforms. Having integrated the state within the party, the Mao administration concentrated its efforts in ideological purification, or in official Marxian parlance, the enhancement of the 'superstructure' ${ }^{5}$. What was to happen in the economic 'base' was left to highlydecentralized territorial units.

Most prominent of these units was arguably the People's Communes (renmin gongshe). These were socio-spatial organizations comprising several thousand households, within which collectivized economic production took place. After the Great Leap Forward (1958-1960) industrialization project led to mass starvation, senior CPC cadres like Liu Shaoqi, Deng Xiaoping, Li Fuchun, Chen Yun and Deng Zihui were keen to revive earlier plans to facilitate individual household production and allow households to retain greater shares of their output (baochan daohu). Fundamental to this downscaling proposal was flexibility - the goal was to increase output and alleviate the deleterious socioeconomic effects of the Great Leap Forward. It was at this point in 1962 that Deng Xiaoping first presented the flexible "yellow cat, black cat" outlook that subsequently undergirded the post1978 reforms:

Comrade Liu Bocheng often uses a Sichuan phrase "Yellow cat, black cat, whichever catches the mice is a good cat". This refers to fighting battles, that we were able to defeat Chiang Kai-shek was because we did not play by old rules, we did not follow old ways of fighting, everything depended on circumstance, what counted was victory. To recover rural production currently also depends on circumstance, that is, the relations of production cannot adopt a fixed and unchanging form, whichever form stimulates the enthusiasm of the masses shall be adopted. (Deng, 7 July 1962; see Deng, 1994: 323; author's translation).

Mao would have none of any "old rules", however. For this and other 'right leaning' 
(youqing) proposals, Liu and Deng were castigated as 'capitalist roaders' (zouzipai) at the onset of the Cultural Revolution in 1966. The CPC's hard-handed negation of householdbased production in the 1960s illustrates two interconnected regulatory logics. First, what the Mao administration wanted was a particular approach to capital accumulation, namely one led by rural collectivization and the systematic transfer of surplus value to industrial projects to fulfill specific economically-nationalistic goals (i.e. surpassing the UK and US and ultimately matching the Soviet Union) ${ }^{6}$. Second, the "relations of production" integral to Deng Xiaoping's concerns had to be premised on and reproduced through a particular territorial form. This territorial form is the People's Communes.

The symbolic and practical values of the Communes are clear. Symbolically, the CPC not only wanted to emulate communes established across the Soviet Union, but to supersede Soviet collectivization. As Mao acknowledges in a 1957 speech: "We are now developing manufacturing and strengthening agricultural industries. We are more courageous than Stalin by launching industrialization within the Communes" (cited in Deng, 1998: 44; author's translation). Practically, it was more manageable for the National Planning Commission, the-then central planning agency in charge of the highly complex agricultural production system, to transmit information to 26,000 communes than if it was done at the next administrative level, the production brigades (shengchan dadui), which numbered around 800,000 units (Jones and Poleman, 1962; Perkins and Yusuf, 1984). Taken together, these two points underscore how the reterritorialization of 'new China' became a precondition and an outcome of an economically nationalistic approach to capital accumulation.

A new round of decentralized governance was launched during the Cultural Revolution to ensure the 'capitalist roaders' would not undermine Maoist economic nationalism. As Donnithorne's (1972) study shows, cell-like administrative units tied hierarchically to the central government were instituted in tandem with the nationalistic 
policy of 'self-sufficiency'. The CPC granted significant autonomy to provincial governments to self-finance developmental projects. In return, the central government enforced a minimal trade policy between provinces. For almost a full decade prior to the 1978 reforms, the 'Chinese economy' resembled a customs union more than a common market; it was an entity with a common barrier against the global economy, within which free trade did not exist. Mao-era China was thus effectively a "cellular economy" that comprised of cell-like, self-sufficient local administrative units (the 'People's Communes' or urban-based enterprises known as gongye danweis).

The concurrent occurrence of political centralization with territorial decentralization since 1949 calls into question the temporal decoupling of the centralization-decentralization relationship. This paper foregrounds two issues. First, the years $1978-1979$ is construed as a temporal watershed that distinguishes the transposition from a centralized era (driven by a powerful central bureaucracy) to a 'transitional' period that is decentralized (and indicative of a deepening of market-like rule). What has since changed is apparently a one-track scalar devolution from a centrally-planned state spatiality to variegated territories driven by 'entrepreneurial' local governments. The preceding discussion has shown, however, that post-Mao regulatory configurations cannot be characterized as a linear scalar shift from the national scale to smaller territorial units. Rather, territorial reconfigurations in the post-Mao era exemplified a qualitative shift from one decentralized "cellular" structure - to re-borrow Donnithorne's (1972) term - to another based on city-regional capital accumulation and provincial-level protectionism (more on this shortly).

Connected to this shift is the second issue: taken as an endogenous phenomenon independent of political centralization, 'decentralization' takes on the appearance of a selfcontained process that shaped the 'miraculous' outcomes of post-1978 economic reforms in/across China. While there is no doubt that some subnational governments in China have put into practice creative socioeconomic policies that produced positive results following the 
delegation of more administrative power, the causal logic of policy innovations need not be related to decentralization in a linear-sequential fashion (i.e. decision to decentralize $\rightarrow$ innovative local policies of/for capital accumulation $\rightarrow$ positive local socioeconomic outcomes). Indeed, this linear-sequential logic is unclear in three ways. First, it does not explain whether the strong economic growth in some regions is really and/or solely due to local policy innovation. Second, it does not explain why some local governments are more innovative than others. Third, this logic suggests China's post-1978 geography of state power is diverging from a top-down mode of regulation when, as the next section will show, the legacy of decentralized governance jumpstarted new rounds of centralizing measures in the 1990 s as well as consolidated the importance of the urban-rural 'dual structure', a sociospatial regulatory tool instituted in 1958. Furthermore, assessing whether "changes" to central-provincial interactions are "genuine" is challenging because an 'objective' yardstick is required to ascertain authenticity. What constitutes objectivity is intrinsically political, however.

Bearing these issues in mind, this paper is careful not to reify decentralized governance as an autonomous driver of post-Mao socioeconomic reforms. As Cai and Treisman (2006: 506) put it, the key reforms that "reshaped China's economy began in the late 1970 s and early 1980s, before any significant decentralization had occurred. In fact, China's authoritarian centralization helped speed the geographical spread of policies found to work well". Along the same vein, Ma (2005: 478; cf. Shen, 2007) observes the "rescaling of China's nation-building efforts downward in the post-1978 reform era represents not so much the retreat and disarticulation of the central state as a rearticulation of state power with a different form of state intervention at lower spatial scales". These findings correspond with Li's (1997: 49) proposal that the central-provincial relationship in China must be conceptualized as a "non-zero-sum, interactive process of conflicts and compromises, whereby genuine changes to the relationship are made." Building on these studies, this 
paper argues that a more fruitful research avenue is to examine whether the territorial reconfiguration of regulatory policies have altered the fundamental roles and objectives of the CPC.

\section{Uneven economic-geographical development: undesirable outcome or developmental precondition?}

The evolution of 'new China' was and remains characterized by uneven economicgeographical development. Empirical studies consistently reveal entrenched income inequality between the urban and the rural meso-scales and between provinces (cf. earlier reviews by Fan, 1995 and Wei, 2007). Donnithorne (1972: 618) notes how "efficient cells do not subsidize the inefficient" following Mao's down-scaling of "self reliance" to individual economic units during the Cultural Revolution, a development that "of course militates against egalitarianism" (cf. Snead, 1975). Inter-provincial income disparities did not narrow between 1952 and 1985, as Tsui (1991) discovers. This corresponded with Lyons' (1991) analysis of output data between 1952 and 1987. Instead of reducing income inequality, Lyons (1991: 499) found "the absolute gaps between richest and poorest widened considerably between the 1950s and the mid-1980s". For this reason, Lyons (1991: 499) concludes that the Mao era "cannot be viewed as a wholly successful implementation of the egalitarian ideals widely thought to underlie the Chinese model of development".

A separate study on real per capita consumption between 1952 and 2000 by Kanbur and Zhang (2005) reinforces the validity of these studies. They identified sharp growth in interprovincial inequality 1) in the buildup to the Great Leap Forward (1955-1960); 2) after the Cultural Revolution began in 1966; and 3) after the Deng administration made a distinct turn to urban-oriented industrialization in the early 1990s. The key finding of this study was the return of urban-rural inequality in 2000 - albeit at higher levels of income - to that of 1978 (ref. statistics collated in Figure 1; cf. Dunford and Li, 2010). The similarity of these 
levels, one before reforms and one two decades after, is empirically significant because it indicates the exacerbation of inequality was not solely an outcome of marketization. By implication, this calls for a qualitative exploration of factors that contributed to uneven development in post-Mao China.

\section{Figure 1 here}

Research indicates enduring uneven development is entwined with the 'scaling up' of the national fiscal system during the 1990s. As mentioned in section 2, power centralization during the Mao era was actualized through decentralized governance, and this strategy severely undermined the financial power of the central government. Tsui (1991) suggests that the connection originated from the launch of the Great Leap Forward industrialization campaign in 1958. The decentralized fiscal governance that accompanied this campaign witnessed the doubling of the share of extra-budgetary revenue, defined as fiscal funds not subject to control or extraction by the central government, in the 1960s. This trend went on to exhibit "a distinct upward trend in the 1970s and 1980s" (Tsui, 1991: 15).

This ability to raise funds independent of the central government directly contributed to unevenness in economic output and standards of living during the Mao era. Wen Tiejun, the long-time economic consultant to the CPC, corroborated this point in a recent interview with Nanfang Ribao:

What is known as localized development began in 1957, when the Soviet Union stopped giving China aid-related investments. The central government's budget fell, this budget became a 'red line' while local budgets were the 'blue lines'. Because there was no more money [in Beijing], there was no true centralization of power in China since the 1950s. At the time, all the older comrades knew of this phrase "central finance is sitting on the slides, local finances are soaring through the skies" [zhongyang caizheng zuo huati, difang caizheng zuo feiji]. In the later part of the 1950s, together with the Great Leap Forward, the entire developmental process was driven by local economies; the central government in fact did not possess the capacity to command the localities. Hence we say, for a long time since the 1950s, the local economy took precedence, it was only until the 1994 fiscal reforms that resource redistribution became half-half. (Interview with Nanfang Ribao, 23 June 2013, author's translation)

Remarkably, local autonomy was enhanced during the first decade of reforms because thethen fiscal system - which mandated a fixed percentage of total local revenue to be 
submitted to the central government - encouraged local governments to expand their operations ${ }^{7}$ but under-report profits of SOEs under their charge. Often these profits would be re-categorized as expenditures in a bid to 'hide wealth within the SOEs' (changfuyuqi) (Interview, senior planner A, Beijing, February 2012). "Between the 1980s and 1990s", planner A adds, "the central government was so weak that there were two instances where they had to go and 'borrow money' from local governments, in each of these instances the amount was 2 to 3 billion RMB [ US\$600m to US\$900m in 1990 prices]" (Ibid.). In September 1993, the-then Chinese Vice Premier, Zhu Rongji, provided a candid clarification of the fiscal position in Beijing: "Currently central finances are confronting severe difficulties, we are in a situation where we can't go on, if we do not suitably concentrate financial revenue and enhance the financial power of the central government, the whole country will eventually be harmed and we won't be able to keep things going" (Zhu, 2011: 360; author's translation). Within a year, as detailed in Box 1, the CPC would unleash fiscal reforms that jumpstarted a phenomenon now widely-known as 'the advancement of the state and the retreat of the people' (guojin mintui).

\section{Box 1 here}

Intertwined with this advancement is the concomitant increase in the political influence of the central government. This development corresponds with the growing theoretical debate on whether effective economic planning was a post-Mao phenomenon (as outlined in section 2). Huang and Chen's (2013) study on fiscal redistribution in China reveals that whenever large-scale central financial support was needed, even in the relatively prosperous coastal city-regions such as Dalian, Shanghai and Shenzhen, political connections to and/or the lobbying of the central government became necessary. Inherited from the Mao-era, this process is what the Chinese state terms "specific purpose transfers" or zhuanxiang caizheng zhuanyi, a redistributive mechanism that is "typically not rule-based and thus subject to political influence" (Huang and Chen, 2013: 534; ref. also Sheng, 2010). 
More noteworthy is the fact that these special purpose transfers constitute the largest components of fiscal redistribution from the central government to individual provinces $^{9}$. The resultant "anti-equalizing" effects of centralized fiscal redistribution, which saw fiscal funds directed to more developed provinces, effectively generates fresh rounds of uneven economic-geographical development. Wen Tiejun puts the positive correlation between fiscal centralization and the central government's political power in contemporary perspective:

Right now the central government's primary mechanism to control the local economies is fiscal transfer payments, through special purpose transfers. Naturally special purpose transfers became the central aspect of the state's financial institution, it is a major institutional gamble. To a large extent, the so-called regional disparities are caused by disparities in capital allocation [by the state]. (Interview with Nanfang Ribao, 23 June 2013; author's translation)

The persistence of centrally-influenced "regional disparities" strongly suggests the "cellular economy' was repurposed rather than thoroughly reconfigured after 1978 (cf. Donnithorne, 1972; World Bank, 1995). To be sure, marketizing reforms introduced new processes in the cellular economic-geographical structure, namely the implementation of household-based production first experimented in the early 1960s (ref. section 2); the gradual development of a private economy (minying jingji) outside the planned system; strategic engagement with foreign capital; and the relaxation of demographic controls. Flows of goods and labor power across the country thus became less place-bound, a marked difference from the Mao-era. However, new empirical data reveals a lack of deeper inter-provincial economic integration despite these reforms. In 2004, the then deputy Minister of Commerce, Huang Hai, acknowledged many local governments relied on legislative mechanisms to generate and legalize a host of discriminatory measures (Zhongguo Qingnianbao, 23 June 2004). In a thorough analysis of data (1978-2007) from China's National Bureau of Statistics (NBS), Villaverde et al (2010: 92) found inter-provincial economic disparities amidst the "striking absence of spatial dependence, which confirms a limited economic relationship between provinces." 
Attributing this phenomenon to the restrictions on internal trade, Villaverde et al's (2010) work supports two interrelated findings by Poncet (2005), namely the fragmentation of China's domestic market along provincial lines through the 1990s and the exacerbation of this fragmentation between 1992 and 1997 (cf. Lee, 1998; Young, 2000). The effects of local protectionism could directly be seen in productivity disparities between export-oriented firms and firms that receive local market protection. As Yang and He (2014: 369) demonstrate, "productive firms enjoying local protection are less likely to export" since they benefit local monopoly advantages; conversely, less productive exporting firms tend to agglomerate to enjoy "exporting spillover effects" that allow them to directly enter international markets. In a separate study on the relationship between local protectionism and firm failure, He and Yang (2015) found firms enjoying direct subsidies and loans from formal institutions are less likely to fail. The critical determinant between survival and shutdown is access to rather than the quantity of support: "[w]hether firms get subsidies and banking loans actually is more important than how much they get since both subsidies and loans represent governmental support" (He and Yang, 2015: 9). These important findings underscore the constitutive effects of inherited subnational barriers to trade on the national economic-geographical configuration. Against these empirical contributions, it can be inferred that the 'cellular' economic-geographical structure and its accompanying protectionist tendencies that characterized Maoist China were reconfigured in relation to post-Mao regulatory and fiscal centralization.

Ironically, the new waves of local protectionism are connected to new centralizing measures. In an earlier survey by the Development Research Centre of the State Council (2004), which established the widespread existence of local protectionism, local government officials justified the augmentation of local fiscal revenues through protectionism; this, as Box 1 shows, was a direct outcome of the central government's decision to re-centralize fiscal revenue collection in 1994. Occurring in tandem was the deepening of Deng 
Xiaoping's "development is the absolute principle" (fazhan shi yingdaoli) mandate. Widelyknown in China as "GDP-ism" (GDP chongbai) and fully promoted by the Jiang Zemin-Zhu Rongji government, this approach based local officials' promotional prospects on GDP growth. Unsurprisingly, these officials relied on administrative borders to create barriers to market entry and in turn 'guarantee growth' (bao zengzhang) (for more on the transfers of administrative personnel around provinces under a nomenklatura personnel system, see Naughton and Yang, 2004; Chien and Gordon, 2008; Xu, 2011) ${ }^{10}$.

Apart from the inherited fiscal system, one other Mao-era institution - the urban-rural dual structure (chengxiang eryuan jiegou) - underpinned the reproduction of uneven development across 'new China'. Deng Xiaoping was able to launch two parallel developmental paths in 1978 because of the territorial and demographic demarcation of the urban and rural. These paths were 1) the spatially-selective 'opening up' to global circulatory capital in the southeastern Special Economic Zones (SEZs) and 2) the reconfiguration of economic production in the rural hinterland, within which more than $80 \%$ of the national population resided at the time, from the commune level to the level of the individual household (in what remains known as the 'Household Responsibility System' (HRS), or jiating lianchan zerenzhi). Yet the unrest that unfolded during the first decade of reforms demonstrates both paths could not run independently. This led to a two-tiered transformation in the 1990s: the convergence of these paths and a concomitant prioritization of the urban (cf. Andreas, 2010).

Finance and assets began to be concentrated by select private owners with the expanded privatization of rural industries, in particular to insiders previously working in the rural industries (Hinton, 1990; Rozelle et al, 2000; Li and Rozelle, 2004). This corresponding search for 'economic efficiency' through 'crowding out' produced rural class polarization and increasing inequality, with a growing number of rural workers either laid off or forced to accept wages significantly lower than those offered in the coastal city-regions (cf. So, 2003; 
Liu, 2006; Hung, 2008; Webber, 2012). Higher wages in the cities took on new significance with the roll-back of rural social services and the decline in rural employment in the same period. As a senior planner in Beijing puts it, the contraction of these capacities was correlated to the dismantling of the People's Communes in and after 1984:

To take as an example, under the commune institution, if an instruction came in from above to build roads, then the commune cadres must think of ways to get the funds through economic production before using the funds to build the roads. Under the current institution, similarly instructions will come from above to build roads or provide other facilities, but the village governments have no money. Because they are not in charge of economic production, they will go around assessing people in the villages for funds, this easily creates situations where funds are extracted illegally, without regard for the necessity and ability of the villagers to pay. Nowadays they even have to borrow from banks or non-authorized agencies, but these [loans] must be paid back. From whom do they get the money? The peasants. (Senior planner B, February 2012, Beijing. Author's translation)

An important observation of this planner is the apparent re-emergence of "bureaucratic capitalism"11, a trait the Mao administration viewed as a primary target of the pre-1949 revolution:

The village governments have become a bureaucratic institution (guanliao tizhi), they rear a bunch of people who have nothing to do with economic production, hence their activities directly burden the peasants. If you look around, what we have today is really a form of bureaucratic capitalism (guanliao zibenzhuyi). (lbid.)

This two-pronged development - the reduction of agriculture-related jobs and the reemergence of 'bureaucratic capitalism' in the rural hinterland - arguably made possible what Naughton (1995) terms 'growing out of the plan'. Corresponding with what Pei (2006) terms 'selective withdrawal', the 'growing out' process was characterized by a 'dual track' approach to production initiated by the former Premier, Zhao Ziyang, in 1984. This approach replaced the Soviet-styled 'planned system' with the defining feature of post-Mao socioeconomic reforms - marketization. While some parts of industrial production remained planned by the central state and anchored the national economy, certain aspects of previously-monopolized industrial sectors were opened up to private buyers and sellers. Surplus goods could be sold at privately-determined prices and producers in these sectors were able to compete directly with the growing non-state economy. The overarching 
objective, to Naughton (1995: 200), was to "expand market forces by limiting the scope of planning, fostering entry, and improving incentives and autonomy for state-run enterprises to operate on the market”. 'Dual track' production culminated in an official acknowledgement in 1993 that all means of production should be geared towards a the development of a 'socialist market economy'. This economically-nationalistic project is now officially termed as "the China Dream".

The gradualism of 'growing out' distinguished the Chinese transition to market-like from the 'big bang' policies of the former Soviet Union and eastern Europe in one major way: there was no corresponding political instability at the national scale. However, one crucial precondition requires emphasis: the 'planned system' Naughton (1995) referred to was effectively an urban-based system. It was a system institutionally, structurally and socially separate from the rural hinterland. This distinction means two-track pricing would be hard to implement in the former Soviet bloc because the state industrial sector in this bloc played a dominant role and the majority of the population was employed by state(-linked) institutions. In contrast, only $18 \%$ of China's population were based in urban-based industrial danweis in 1978. Contrasting the pressures for total socioeconomic restructuring in the former Soviet bloc, the CPC did not have to induce unemployment in order to facilitate market-based reforms. Zhao's 'dual track' approach was therefore capable of driving non-state economic growth because of Mao's apartheid-like policy to segregate the rural population (and its associated economic activities) from the urban. With state monopoly relaxed in the industrial sectors, the platform was established for the rural-based economic actors to engage in direct competition with urban-based SOEs. Township and Village Enterprises (TVEs) gained market entry and stimulated competition (Naughton, 1994). At the same time, the approach also facilitated the launch of the biggest non-state market of all - the market for surplus rural labor power. 
If there was a primary corollary of post-Mao marketization, it was the seamless production of a 'floating' labor market that powered the exponential GDP growth in China since the early 2000s (cf. Chan and Buckingham, 2008; Lim, 2014b). Within this market, peasant migrant workers could be priced solely as a-social labor power. Since the early 1990s, this has taken place in segmented intra-urban labor markets comprising what Fan (2002: 103) terms "the elite, the natives and the outsiders". Without corresponding sociospatial protection, these "outsiders" became less rooted to their new urban destinations; yet without corresponding growth in employment opportunities in their rural 'hometowns', they could only continue to 'float' between city-regions to seek employment (Solinger, 1999; Chan, 2010a, 2010b). Peng Xizhe, a leading public policy scholar from Shanghai's Fudan University, puts the situation in perspective:

The reason why rural workers can engage in economic activities at much lower wages in the cities is due to this two-tiered social status. If there is no hukou institution in China, rural workers will hope to have the same lifestyles, the same wages, and the same working conditions as those living in cities. Yet because one continues to feel s/he is a peasant [in the cities], that the 'home' is in the countryside, the feeling of being in the city would be for the purpose of earning some income. So long as wages are acceptable [in relation to those in the countryside], s/he will be willing to work. This phenomenon is an important precondition of the existence of low-cost labor in China. (Xinhua, 13 August 2009: n.p.; author's translation)

Two distinct functions constitute this important precondition. First, it eases the financial burden on municipal governments to provide social welfare. This consequently allows these governments to concentrate on attracting and developing factors of production necessary to embed capital. Second, it ensures the labor supply is geographically elastic to shifts in effective demand for labor power (which to a large extent is derived demand, due to the export-orientation of many labor-intensive industries along the coastal seaboard after the 2001 WTO accession). The second economic function is particularly critical in times of crisis because, in reaction to crisis-induced unemployment, the hukou institution makes it administratively possible to mandate migrants to return to their place of household registration. He Xuefeng, director of the China Rural Governance Research Center in Huazhong University of Science and Technology, crisply describes the function of the dual 
structure: "At the current stage of development in China, and viewed from China's position in the global division of labor, there will be a large underclass that has low pay and very uncertain employment conditions. Because of the existing structure, this underclass could still move freely between the urban and rural areas" (Interview with Nanfeng Chuang, 14 January 2014; author's translation; cf. He, 2010).

The socioeconomic logic of retaining rural 'territorial absorbers' is highlighted by the Guangdong provincial government's swift response to the 2008 global financial crisis. A "double relocation" industrial policy (shuang zhuanyi), also known as "emptying the cage to change the birds' (tenglong huanniao), was instituted to relocate unwanted industries and the labor power they employ (the 'birds') away from the Pearl River Delta (the 'cage'). While it was expected that this restructuring would result in a temporary dip in economic performance, the official employment figures in Guangdong province were positive even after the crisis struck in 2008 . Nationally, the published unemployment rate was under $10 \%$. This rosy picture was complicated after Wen Jiabao, the-then Premier, acknowledged in a meeting with foreign delegates in 2010 that 200 million people were unemployed (China Daily, 23 March 2010). Relative to the total population ( 1.38 billion), this translates to a $14.5 \%$ unemployment rate; the rate becomes $20 \%$ when measured against the total working population ( 1 billion).

In relation to official accounts from Guangdong, Wen's speech strongly suggests unemployment that should be concentrated within Guangdong, the most attractive destination for migrant workers across the country when the crisis struck in 2008, was successfully 'relocated' to other provinces. This 'exportation' not only explains why 200 million people (a substantial number who would have been working in the Pearl River Delta) were unemployed across China in the aftermath of the crisis while the official employment growth rates remained positive in Guangdong. Viewed at the national scale, it foregrounds the capacity of the 1958 urban-rural dual structure to subordinate the 'floating population' to 
the demands and crisis tendencies of transnational circulatory capital (of which the CPC is now an integral part), just as their subservience during and after the crumbling industrialization efforts strongly surprised Mao in the 1960s that he exclaimed: "Hao ah! [Marvelous!] You whistle and 200 million people come, you wave and they go, without the CPC in power, which party can achieve this?!" (People's Daily, 14 October 2013; author's translation).

It becomes evident, then, that the 'growing out of a plan' or 'selective withdrawal' process in post-Mao China was not just about the relaxation of state monopolies in the hitherto urban-based 'planned system'; the 1958 urban-rural dual structure was a vital enabler. More importantly, it continues to underpin contemporary industrial policies. This reaffirms Pei's (2006: 26) observation that the gradualist approach worked because "it has allowed Chinese leaders fully to exploit the structural advantages provided by favorable initial conditions". A striking feature is its continued reliance on the Maoist approach to "use the rural to support the urban industries' (yinong chugong). As He, (2010), Chan (2010a) and $\mathrm{Wu}(2015)$ have shown, growth-oriented planning occurred in tandem with the strategic repurposing of the dual structure. It might thus be helpful to consider whether 'rational' central planning capacities have, as proposed by Wen Tiejun, Qin Hui and Jin Yan, emerged only after the 1978 reforms (cf. section 2).

Taken together, the literature on uneven development in post-1949 'new China' illustrates perpetual CPC rule as a contingency - a socio-spatial contingency. At the inception of reforms in the 1980s, the Deng Xiaoping regime had to work with or around the previously mentioned regulatory logics of the Mao era. Breaking off these legacies too suddenly could unsettle the nascent coherence of a political structure painstakingly built up by the Mao administration. For this reason, experimental policies were introduced through the HRS and SEZs. The social conflicts that since accompanied state-driven capital accumulation - including those emanating from growing exposure to crisis tendencies in 
the global economy - had to be pre-empted or overcome through territorially-targeted policy adjustments. What ensued was the reproduction of uneven development. Buttressing this preference for more 'flexible' economic reforms is an enduring Maoist political logic first repurposed by Deng and subsequently adopted by his successors Jiang Zemin, Hu Jintao and Xi Jinping: socio-political liberalism is not and need not be a corollary of market-like rule. Bao Tong (2008: n.p.), the former aide of Zhao Ziyang and a key participant in reforms of the 1980s, sheds light on the rationale of Deng's reforms:

Once you grasp the logic of saving the Party, it is possible to get a basic understanding of Deng Xiaoping's logic. Everything he did was done to save the Party. Saving the Party required boosting productivity. So to catch the "mouse" of saving the Party, we needed the "cat" of the market economy. It was for this reason that Deng Xiaoping supported economic reforms with all his might. He deserves to be credited as a supporter of economic reforms, even though he didn't care much for economics and didn't understand the market; and he was their most powerful supporter. However, his goal was still to save the Party, and for that reason he was a fierce protector of Party power and status. Just 18 months after the inception of economic reforms, he was quick to stamp out any small green shoots of "liberalism" in a thorough attack, lest they take root and flourish in a change in climate and strike at the heart of the Party.

Identifying transformative change in the context of this logic requires a robust re-evaluation of uneven development in post-1949 China. To begin, it would be helpful to move beyond measuring whether inter-regional inequality is inherently negative or unethical vis-à-vis the CPC's self-proclaimed quest for socialism. As this section has shown, institutional change within the sprawling party-state apparatus is not constituted by a one-track movement from spatial egalitarianism in the Mao era towards greater fragmentation in the 'transitional' present. Rather, as presented in Table 1, the evolutionary process is characterized by the interaction of multiple regulatory layers, each with their distinct geographical expressions, with inherited institutions. Chinese politico-economic development is thus more accurately a complex palimpsest: some Mao-era logics of socioeconomic regulation (like the People's Communes and the 'permanent revolution' campaign) may have gone, but others have been re-purposed with new institutions designed to facilitate market-like rule (see far right column). On the basis of this phenomenon, the theoretical challenge is to explain how and 
why territorially-fragmented logics of socioeconomic regulation function at the national scale to preserve CPC power.

\section{Table 1 here}

\section{Conclusion}

Is China an exceptional case because its Leninist system has been able to sustain change along the lines of a mixed economy? Or is Chinese exceptionalism something of an illusion which obscures an underlying conformity with the fundamental logic of a Soviet-style system - the fusion of politics and economics? It is quite possible to give affirmative answers to both questions. - Steven M. Goldstein (1995: 1110)

In carrying out the construction of socialism by our party, leaders, and people, there are two periods, [one that is] before reform and liberalization and [one] after that...Although there were major differences in the ideological direction, orientation, and policies in the implementation of socialist construction during these two historical periods, they cannot be disconnected. Furthermore, they are not oppositional. One cannot use the historical period following reform and liberalization to negate the historical period prior to reform and liberalization, and vice versa. - Xi Jinping, President of China (People's Daily, 6 January 2013)

When Mao Zedong told Poul Hartling in 1974 that efforts at building a socialist state used and reproduced the methods of the "old society", he was arguably aware of the limits to driving capital accumulation on the basis of instituted uneven development and geoeconomic insulation (cf. section 1). Yet, in selecting Hua Guofeng (rather than Deng Xiaoping) as his official successor, Mao highlighted the importance of retaining Stalinistic logics of socioeconomic regulation the CPC so painstakingly cultivated in the 1950 s and $60 \mathrm{~s}^{12}$. While it might appear at first that Deng's success at bypassing Hua to launch marketoriented reforms in 1978 marked a clear separation from Mao's reign, subsequent research on the interaction between Mao-era regulatory logics and successive waves of post-Mao reforms presents a more complicated picture of continuity and change. This paper is an evaluation of this interaction.

Questioning the notion that socioeconomic reforms in the post-Mao era represent a linear-sequential devolution that transformed the Chinese political economy (see, e.g., such assumptions in Pei, 2006; Huang, 2008; Coase and Wang, 2012), this paper developed critical reviews that demonstrate how centralized political power was never compromised 
by new waves of decentralization and uneven development. Contrasting the drastic changes in the former Soviet bloc, Deng and his successors repurposed central political institutions through decentralized governance, territorially-targeted policy experimentation and the reproduction of regulatory uneven development. Rather than constitute a one-track historical movement from centralized state-socialism to a decentralized market regime, changes that took place produced a quasi-exceptional process in which Leninist socialism co-exists with marketization to produce new spatial logics of socioeconomic regulation (cf. Howell, 2006; Wei, 2007; Li and Wu, 2012; Lim, 2014a). There is no eclipse of one national "system" (or paradigm) by another.

Indeed, new reform initiatives and institutional continuities are co-constitutive. As the current Chinese President, Xi Jinping, acknowledges, the political economic history of 'new China' cannot be characterized by two distinct and oppositional 30-year periods. While there were distinct differences in the ways the economic production and demographic flows were regulated by post-Mao regimes, the primary regulatory objectives of these regimes arguably did not differ from Mao's (ref. sections 2 and 3). These regimes all sought to deepen the foundational status of the CPC as the government of China against continuous threats to regime stability (e.g. the Korean war, fears of Kuomintang resurgence, the Tiananmen protests, ethnic tensions in Xinjiang and Tibet, etc.) and all pursued economic nationalism through state-led capital accumulation. What has changed were the methods - or, more specifically, the spatial strategies - to achieve these objectives. Mao chose the 'cellular' organization of the People's Communes and geoeconomic insulation, even to the extent of shutting out Soviet influence during the 1960s; Deng and his successors sought to engage and ultimately integrate with the global system of capitalism through policy experimentation in targeted territories.

While these approaches generated contradictions and led to new reforms, many inherited institutions were never fully abandoned (ref. Table 1, far right column). For Mao, 
the aftermath of the Great Leap Forward could be superseded through successive rounds of political campaigns, the resolute suppression of household-based production and the retention of key regulatory logics of Stalin's regime, primarily the harsh treatment of dissenters, the collectivization of production and the use of the 'price scissors' (jiage jiandaocha) approach to capital accumulation (ref. section 2). In response, Deng and his successors instituted market-like rule while reinforcing at the same time the central government's politico-economic control. This was primarily characterized by the introduction of individual initiatives in economic production in the rural hinterland (which has since been extended to the cities); the launch of successive rounds of geographicallytargeted experimentation to embed transnational circulatory capital; the simultaneous reconfiguration of key Mao-era institutions such as collective/state landownership, the urban-rural dual structure and a financial system dominated by state-linked institutions; and, last but not least, the readiness to intervene in market functions "without hesitation", as exemplified by its decisive attempt to dictate stock market trading in the summer of 2015 (Rawski, 1995; Naughton, 1995; Ong, 2004; Zhu, 2007; Heilmann, 2009; Walter and Howie, 2011; People's Daily, 20 July 2015; see far right column in Table 1). It is apparent from these developments that the enlargement of capital, which encompasses both the state and non-state sectors, has been entwined with its subsumption to party goals in the post-Mao era. As Zhang (2013: 1614) puts it, "the political power of capital in China remains fundamentally embedded in, and interlaced with, the sprawling institutional machinery of the Leninist party-state and the political capacities of the CCP".

It would be more apt, then, to conceptualize politico-economic evolution in post1949 'new China' as a cumulative process through which place-specific reforms are layered on inherited logics of socioeconomic regulation. Emerging from this regular re-layering is a multi-dimensional state spatiality that is connected to the global economy in highly uneven ways. In turn, it determines whether the CPC can continue to govern the Chinese political 
economy as a unitary and hierarchical political system. The old 'planned system' may have given way to market-like governance, but the logics of the market have become the baseline from which new planning capacities are developed by the party-state apparatus. While 'withdrawal' has taken place in 'select' domains, as Pei (2006) rightly points out, there is reinforcement of state power in others (cf. Zhang, 2013; Zhu, 2013; Wu, 2015). The rollback of political capacities may be apparent when it is viewed in relation to the inherited and seemingly static institutional template (e.g. HRS vs. Maoist collective production), but it is never a zero-sum process. This points to the need for a new framework that is sensitive to the complex relations between institutional path-dependency, policy experimentation and the proactive reconfiguration of regulatory scales for capital accumulation. Indeed, if Wen Tiejun and other Chinese 'New Left' scholars are correct in claiming that central socioeconomic planning is only blossoming in the current conjuncture (ref. section 2), the crucial empirical question would be whether and how this planning could work through an overarching process the CPC established since Deng's reforms, namely the feedback loop between territorially-targeted policy reforms, global economic-geographical competitiveness and central(ized) political power. Addressing this question not only indicates whether the

CPC is developing more 'rational' central planning capacities relative to the Mao era, it might also generate new theoretical insights on how socialism in one country could be actualized through deepening integration with the global system of capitalism.

\section{Acknowledgements}

I would like to thank the editor-in-chief, John Agnew; the co-editor, Bae-Gyoon Park; and the anonymous referees for their helpful comments. My gratitude also goes to Trevor Barnes and Jamie Peck for their pre-submission feedback. The lovely hours of writing were made possible by the continuous support and encouragement from my wife, Stephanie Lim - thank you. 


\section{Notes}

${ }^{1}$ That these three commodities, deemed 'fictitious' by Karl Marx, were placed under public ownership is in itself symbolic.

2 The reference to 'socialism' in this paper does not reflect nor impose a normative conceptualization. Following Whyte (2010), emphasis is placed on the CPC's self-proclaimed quest for socialism as an empirical fact rather than what 'socialism' means when it is measured against a particular template (e.g. Marx's version based on the experience of western capitalist economies or Lenin's version based on the largely agrarian Russian economy). While the CPC claims both Marx's and Lenin's versions to be relevant to its quest (at least ideologically), its official commitment to creating 'socialism with Chinese characteristics' is path-setting given the collapse of the socialist internationalist movement. What 'socialism' means for the CPC is thereby an empirical question, to be explored in tandem with marketization reforms and the emergence of new planning capacities in the party-state apparatus.

${ }^{3}$ This was possible because the Mao administration had deliberately emphasized a decentralized mode of governance (see discussion shortly).

${ }^{4}$ With the implementation of the $12^{\text {th }}$ Five Year Plan in 2012, the Chinese central government has regularly committed to reduce its GDP growth target to a 'new normal' of around $8 \%$. This figure was revised to $7 \%$ in 2015 as the CPC, in Premier Li Keqiang's terms, sought to fight "systemic, institutional and structural problems" (The Guardian, 8 March 2015). A major policy to address this problem was launched in September 2014 and was targeted directly at reducing the powers of prefecture- and county-level cities (see elaboration in Box 1).

${ }^{5}$ The 'superstructure' in Marxian terms refers to social aspects such as culture, ideology and religion. The 'base' refers to the means and social relations of economic production. Economic production in this regard refers to the creation of things needed by society. Marxian logic states the economic 'base' generates the 'superstructure', a logic turned on its head in the latter half of Maoist rule. Distinguishing his approach from that of Stalin, Mao argued in the late 1960s that the Stalinist regime "speak only of the production relations, not of the superstructure nor politics, nor the role of the people." (Mao, 1977: 136). Through the Cultural Revolution (which officially lasted between 1966 and 1976), Mao went on to prioritize ideological purity over economic production. It was arguably because of this that the Soviets subsequently charged the CPC of moving from the fundamental tenets of Marxism-Leninism towards a new path of Maoist voluntarism.

${ }^{6}$ While the primary - and well-documented - expressions of economic nationalism by the CPC during the Mao era was its aim to 'catch up with the UK and surpass the US' (zhuiying ganmei), a more thorough historical exploration reveals its ultimate goal could be to match, if not surpass, the Soviet Union. As Mao puts it tellingly in December 1957: "We can only copy the Soviet Union in the fundamental sense, even so I feel dissatisfied, I feel uncomfortable...The Soviets produced more than 4 million tonnes of iron in 1921, this increased to 18 million tonnes in 1940. Both the Soviet Union and China are socialist countries, could we not accelerate and expand production, could we not use a method that is bigger, faster, better and more economical to build socialism?" (in Deng, 1998: 44, 715; author's translation). How this competitive streak to match the Soviet economic achievements contributed to the economic-geographical reconfiguration of 'new China' remains an under-explored research topic in geographical political economy.

${ }^{7}$ The situation was exacerbated by a new initiative known as 'baoying bu baokui' that encouraged retention of profits but lack of responsibility when losses were incurred. This institution was subsequently reformed as SOEs were mandated to function more like private corporate entities. 8 "Special purpose transfers", Huang and Chen (2013: 538) explain, are "commonly used by the central government to provide incentives for local governments to undertake specific policies, programs or activities favored by the central government." From 2007 data, for instance, it could be seen that while many poor provinces like Tibet, Guangxi and Jilin have benefited from these transfers, a high amount also goes to Shanghai, one of the richest province-level areas in China. Through enhancing the development of Shanghai, coastal-interior unevenness was reproduced, if not reinforced. 
${ }^{9}$ The cities of Beijing, Chongqing, Shanghai and Tianjin are classified as province-level administrative units directly governed by the central government (zhixiashi). Under this classification, these cities are treated at the same level as provinces like Guangdong and Fujian.

${ }^{10}$ While also existent during the Mao era, it became more apparent that an informal, patron-client structure complemented this nomenklatura since 1978. Crucially, as Burns (1999: 581) shows, the nomenklatura system became "more disciplined" in the post-Mao era relative to the 1950s. Burns' (2003) subsequent study found that despite official 'downsizing' of the party-state, public employment actually increased. These findings complement subsequent research that reveals how this Mao-era institution has been fortified by and expanded in tandem with marketizing reforms (Naughton, 2008; Brødsgaard, 2012; Lin and Milhaupt, 2013). It is within this system that CPC cadres are deployed to specific territories and encouraged to introduce bottom-up initiatives.

${ }^{11}$ Given constraints of space, it would not be possible to elaborate on the concept of 'bureaucratic capitalism' and its empirical manifestations in post-1949 China. By definition, this refers to economic rent-seeking from political actors through the (ab)use of political powers. Mao Zedong made it clear in March 1948 that 'bureaucratic capitalism' was to be 'overturned' together with feudalism and imperialism in the Chinese revolution (Mao, 1991: 1182).

${ }^{12}$ Hua Guofeng would immediately declare a "Two Whatevers" (liangge fanshi) approach to managing Mao's legacies: 1) We will resolutely uphold whatever policy decisions Chairman Mao made; and 2) We will unswervingly follow whatever instructions Chairman Mao gave. This approach indicates Hua would have extended the quasi-Stalinistic regulatory logics across China if he had remained in power. Hua was, however, out-maneuvered by Deng and his strong support network in 1978.

\section{References}

Andreas, J. (2010). A Shanghai model? On capitalism with Chinese characteristics. New Left Review 65: 63-85.

Bao, T. (2008) 'Two Faces' of Deng Xiaoping. Translated and published by Radio Free Asia. Retrieved online on 10 June 2015 at: http://www.rfa.org/english/news/china/baotong12292008165015.html

Bernstein, T. P. and Li, H.-Y. (eds.)(2010) China Learns from the Soviet Union, 1949Present. Plymouth, UK: Lexington Books.

Breslin, S. (2000) Decentralisation, Globalisation and China's Partial Re-engagement with the Global Economy. New Political Economy 5 (2): 205-226.

Breslin, S. (2014) Financial transitions in the PRC: Banking on the state? Third World Quarterly 35(6): 996-1013.

Brødsgaard, K. E. (2012). Politics and business group formation in China: the party in control?. The China Quarterly, 211: 624-648.

Burns, J. P. (1999). The People's Republic of China at 50: national political reform. The China Quarterly, 159: 580-594.

Burns, J. P. (2003). Downsizing" the Chinese state: Government retrenchment in the 1990s. The China Quarterly, 175: 775-802. 
Cai, H., and Treisman, D. (2006). Did government decentralization cause China's economic miracle? World Politics, 58(4): 505-535.

Caixin (2015) How Beijing intervened to save China's stocks. 16 July. Accessed on 18 July 2015 at: http://english.caixin.com/2015-07-16/100829521.html

CCCPC Party Literature Research Office (1998) Jianguo yilai Mao Zedong Wengao Vol. 13. Beijing: Zhongyang Wenxian Chubanshe.

Chan, K. W. (2010a) A China Paradox: Migrant Labor Shortage amidst Rural Labor Supply Abundance. Eurasian Geography and Economics 51(4): 513-530.

Chan, K. W. (2010b) "The Global Financial Crisis and Migrant Workers in China: 'There is No Future as a Labourer; Returning to the Village has No Meaning'" International Journal of Urban and Regional Research 34(3): 659-77.

Chan, K. W. and Buckingham, W. (2008). Is China abolishing the hukou system?. The China Quarterly, 195, 582-606.

Chien, S. S. (2010). Economic freedom and political control in post-Mao China: A perspective of upward accountability and asymmetric decentralization. Asian Journal of Political Science 18(1): 69-89.

Chien, S.-S. and I. Gordon (2008) Territorial competition in China and the West. Regional Studies 42(1): 1-18.

China Daily (2010) Wen upbeat on US relations despite strains. 23 March.

Chung J. H. (2000) Central Control and Local Discretion in China-Leadership and Implementation During Post-Mao Decollectivization New York: Oxford University Press.

Coase, R. and Wang, N. (2012) How China Became Capitalist London: Palgrave.

Deng, L. (1998) Mao Zedong du shehui zhuyi zhengzhi jingjixue pizhu he tanhua. [Mao Zedong's commandments and speeches on reading socialist political economy] Beijing: PRC Historical Society.

Development Research Center of the State Council (DRCSC) (2004) A report on local protectionism in China. References for Economic Research 18: 31-38.

Dikötter, F. (2011) Mao’s Great Famine. New York: Walker \& Co.

Donnithorne, A. (1972) China's Cellular Economy: Some Economic Trends since the Cultural Revolution. The China Quarterly 52: 605-619.

Dunford, M., and Li, L. (2010). Chinese spatial inequalities and spatial policies. Geography Compass, 4(8): 1039-1054.

Economy, E. C. (2011). The River Runs Black: The Environmental Challenge to China's Future. Ithaca: Cornell University Press. 
Fan, C. C. (1995). Of belts and ladders: state policy and uneven regional development in post-Mao China. Annals of the Association of American Geographers, 85(3): 421-449.

Fan, C. C. (1997). Uneven development and beyond: regional development theory in postMao China. International Journal of Urban and Regional Research, 21(4): 620-639.

Fan, C. C. (2002). The elite, the natives, and the outsiders: Migration and labor market segmentation in urban China. Annals of the Association of American Geographers, 92(1), 103-124.

Goldstein, S. M. (1995). China in transition: The political foundations of incremental reform. The China Quarterly, 144, 1105-1131.

Goodman, D. S. (2004). The Campaign to "Open up the West": National, Provincial-level and Local Perspectives. The China Quarterly 178: 317-334.

Gore, L. (1999) The communist legacy in post-Mao economic growth. The China Journal 41: 25-54.

Greenhalgh, S. and Winckler, E. A. (2005) Governing China's Population: From Leninist to Neoliberal Biopolitics. Stanford: Stanford University Press.

He, C. and Yang, R. (2015). Determinants of Firm Failure: Empirical Evidence from China. Growth and Change. Advanced access: 1-21. DOI: 10.1111/grow.12116

He, S. and Wu, F. (2009) China's emerging neoliberal urbanism: Perspectives from urban redevelopment. Antipode 41(2): 282-304.

He, X. (2010) Diquan de luoji: Zhongguo nongcun tudi zhidu xiang hechu qu [Logics of land rights: where is the rural land institution in China heading?]. Beijing: Zhongguo Zhengfa Daxue Chubanshe.

Heilmann, S. and Perry, E. (eds)(2011) Mao's Invisible Hand: The Political Foundations of Adaptive Governance in China. Cambridge, MA: Harvard University Press.

Hinton, W. (1990). The Great Reversal: The Privatization of China. New York: Monthly Review Press.

Howell, J. (2006) Reflections on the Chinese state. Development and Change 37(2): 273297.

Hsueh, R. (2011) China's Regulatory State: A New Strategy for Globalization. Ithaca, NY: Cornell University Press.

Huang, B., and Chen, K. (2012) Are intergovernmental transfers in China equalizing?. China Economic Review, 23(3): 534-551.

Huang, Y. (1996). Central-local relations in China during the reform era: the economic and institutional dimensions. World Development, 24(4), 655-672. 
Huang, Y. (2008) Capitalism with Chinese Characteristics: Entrepreneurship and the State. Cambridge University Press.

Huang, Y. and Yang, D. L. (1996). The political dynamics of regulatory change: speculation and regulation in the real estate sector. Journal of Contemporary China 5(12): 171-185.

Jones, P. P., and Poleman, T. T. (1962) "Communes and the agricultural crisis in Communist China." Population 600(500):1-20.

Kanbur, R. and Zhang, X. (2005). Fifty years of regional inequality in China: a journey through central planning, reform, and openness. Review of development Economics, 9(1): 87-106.

Lan, J., Kakinaka, M., and Huang, X. (2012). Foreign direct investment, human capital and environmental pollution in China. Environmental and Resource Economics 51(2): 255-275.

Lee, P. K. (1998) Local economic protectionism in China's economic reform. Development Policy Review 16: 281-303.

Li, P. (1988) 1988 nian guowuyuan zhengfu gongzuo baogao [1988 State Council Work Report], 25 March. Accessed on 6 May 2014 at: http://www.gov.cn/test/200602/16/content_200865.htm

$\mathrm{Li}, \mathrm{Y}$. , and $\mathrm{Wu}, \mathrm{F}$. (2012). The transformation of regional governance in China: The rescaling of statehood. Progress in Planning, 78(2): 55-99.

Lin, N. (2011) Capitalism in China: a centrally managed capitalism (CMC) and its future. Management and Organization Review 7:1 63-96.

Lin, L. W. and Milhaupt, C. J. (2013). We are the (national) champions: Understanding the mechanisms of state capitalism in China. Stan. L. Rev., 65: 697-760.

Lim, K. F. (2014a). 'Socialism with Chinese characteristics': Uneven development, variegated neoliberalization and the dialectical differentiation of state spatiality. Progress in Human Geography, 38(2): 221-247.

Lim, K. F. (2014b). Spatial egalitarianism as a social 'counter-movement': on socioeconomic reforms in Chongqing. Economy and Society, 43(3), 455-493.

Lyons, T. P. (1991) Interprovincial disparities in China: output and consumption, 1952 1987. Economic Development and Cultural Change, 39(3): 471-506.

Ma, L .J. C. (2005). Urban Administrative Restructuring: Changing Scale Relations and Local Economic Development in China. Political Geography, 24 (4), 477-497.

Mao, T. (1977) A Critique of Soviet Economics. Translated by Moss Roberts. New York and London: Monthly Review Press.

Mao, Z. (1991) Mao Zedong Xuanji Vol. 4 Beijing: Renmin Chubanshe. 
Mao, Z. (1992) Jianguo yilai Mao Zedong wengao Vol. 7. Beijing: Zhongyang Wenxian Chubanshe.

Mao, Z. (1999) Mao Zedong Wenji Vol. 7. Beijing: Renmin Chubanshe.

Montinola, G., Qian, Y., \& Weingast, B. R. (1995). Federalism, chinese style. World Politics, 48(1): 50-81.

Lawrence, S. and Martin, M. F. (2013). Understanding China's political system. CRS Report for Congress. 20 March.

Nanfang Ribao (2013) Wen Tiejun: Chengzhenhua shi yingdui weiji de xianshou [Wen Tiejun: Urbanization is a method of crisis preemption]. 23 June.

Nanfeng Chuang (2014) Xiangcun zhili yanjiu zhuanjia: Chengxiang eryuanjiegou tizhi shi dui nongmin de boduo [Village governance expert: Urban-rural dual structure is exploitative of peasants]. 14 January.

Naughton, B. (1994) Chinese Institutional Innovation and Privatization from Below. The American Economic Review 84(2): 266-270.

Naughton, B. (1995) Growing Out of the Plan: Chinese Economic Reform, 1978-1993 Cambridge: Cambridge University Press.

Naughton, B. (2008). A political economy of China's economic transition. China's great economic transformation. In L. Brandt and T. G. Rawski (eds.) China's Great Economic Transformation, Cambridge: Cambridge University Press, pp. 91-135.

Naughton, B. J., \& Yang, D. L. (Eds.). (2004). Holding China together: Diversity and National Integration in the post-Deng era. Cambridge: Cambridge University Press.

Oi, J. C. (1992) Fiscal Reform and the Economic Foundations of Local State Corporatism in China. World Politics 45(1): 99-126.

Ong, A. (2004) "The Chinese axis: zoning technologies and variegated sovereignty" Journal of East Asian Studies, 4: 69-96.

Pan, J. and J. Li, (2011) Fangdichan Lanpishu: Zhongguo Fangdichan Fazhan Baogao [Development report of real estate development in China]. Beijing: Zhongguo Sheke Wenxian.

Peck, J. and Zhang, J. (2013). A variety of capitalism...with Chinese characteristics?. Journal of Economic Geography, 13(3), 357-396.

Pei, M. (2006) China's Trapped Transition: The Limits of Developmental Autocracy Cambridge, MA: Harvard University Press.

People’s Daily (1988) Dang Zhongyang Guowuyuan Zuochu Jueding Qingli 
Zhengdun Quanguo Gelei Gongsi [The Party Central Committee and State Council Work Department Decision to Reorganize National Accumulation Organisations], 14 Oct.

People's Daily (2013) Haobu dongyao jianchi he fazhan Zhongguo tese shehuizhuyi, zai shixianzhong buduan yousuo faxian yousuo chuangzao yousuo qianjin. [The unhesitating insistence and development of socialism with Chinese characteristics, to discover, innovate and advance through practice]. 6 January.

People's Daily (2015) Gushi weiji ganyu shi guoji guanli [Intervention in stock market crisis is an international convention]. 20 July.

Perkins, D. and Yusuf, S. 1984. Rural Development in China. Baltimore: Johns Hopkins University Press.

Qian, Y. and Weingast, B. (1995) China's Transitions to Markets: Market Preserving Federalism, Chinese Style. Essays in Public Policy: no. 55. Stanford: Hoover Institution Press.

Qian, Y. and Roland, G. (1996) Federalism and the Soft Budget Constraint. American Economic Review, 88(5): 1143-62.

Qin, H. (2004) Shixian Zhiyou [Freedom of praxis]. Hangzhou: Zhejiang Renmin Chubanshe.

Qin, H. and Jin, Y. (2012) Shinian cangsang: Dongou zhuguo de jingjishehui zhuangui yu sixiang bianqian [10 years of anguish: Socioeconomic and philosophical changes in various Eastern European countries] Beijing: Dongfang Chubanshe.

Qu, H. (2012) “Qu Hongbin: Guangdong moshi yu Chongqing moshi bijiao”. [Qu Hoingbin: comparison of the Guangdong and Chongqing 'models']. Accessed 15 April 2013 at: http://comments.caijing.com.cn/2012-05-04/111837075.html

Poncet, S. (2005). A fragmented China: measure and determinants of Chinese domestic market disintegration. Review of International Economics, 13(3): 409-430.

Rawski, T. G. (1995). Implications of China's Reform Experience. The China Quarterly, 144, 1150-1173.

Remick, E. J. (2002) The significance of variation in local states: the case of twentieth century China. Comparative Politics 34: 399-418.

Rozelle, S., Park, A., Huang, J., \& Jin, H. (2000). "Bureaucrat to entrepreneur: the changing role of the state in China's grain economy." Economic Development and Cultural Change, $48(2), 227-252$.

Shen, C., Jin, J., and Zou, H. F. (2012). Fiscal Decentralization in China: History, Impact, Challenges and Next Steps. Annals of Economics \& Finance, 13(1): 1-51. 
Shen, J. (2007). Scale, state and the city: Urban transformation in post-reform China. Habitat International, 31(3): 303-316.

Sheng, Y. (2010) Economic Openness and Territorial Politics in China. New York: Cambridge University Press.

Snead, W. G. (1975). Self-reliance, internal trade and China's economic structure. The China Quarterly, 62: 302-308.

Solinger, D. (1989) "Capitalist Measures with Chinese Characteristics." Problems of Communism 38(1): 19-33.

South China Morning Post (2015) Beijing says it must intervene in markets 'when necessary', in fresh defence of bailout. 23 July.

The Guardian (2015) China lowers growth target to $7 \%$ as it fights 'deep-seated' economic problems. 8 March.

Tsai, K. S. (2004). Off balance: The unintended consequences of fiscal federalism in China. Journal of Chinese Political Science, 9(2): 1-26.

Tsing, Y. (2010) The Great Urban Transformation: Politics of Land and Property in China Oxford: Oxford University Press.

Tsui, K. Y. (1991). China's regional inequality, 1952-1985. Journal of Comparative Economics 15(1): 1-21.

Villaverde, J., Maza, A., and Ramasamy, B. (2010). Provincial Disparities in Post-reform China. China \& World Economy 18(2): 73-95.

Walter, C. E. and Howie, F. J. (2011). Red Capitalism: the Fragile Financial Foundation of China's Extraordinary Rise. Singapore: John Wiley \& Sons.

Wedeman, A. (2001). Incompetence, noise, and fear in central-local relations in China. Studies in Comparative International Development 35(4): 59-83.

Wei, C.X.G. (2011) “Mao's Legacy Revisited: Its Lasting Impact on China and Post-Mao Era Reform” Asian Politics \& Policy 3(1): 3-27.

Wei, Y. H. D. (2007). Regional development in China: transitional institutions, embedded globalization, and hybrid economies. Eurasian Geography and Economics, 48(1): 16-36.

Wei, Y. H. D. (2013). Regional development in China: states, globalization and inequality. London and New York: Routledge.

Whyte M. K. (2010) The paradoxes of rural-urban inequality in contemporary China. In M.K. Whyte (ed.) One Country, Two Societies: Rural-Urban Inequality in Contemporary China. Cambridge, MA: Harvard University Press, pp. 1-25. 
World Bank (1995) Macroeconomic Stability in a Decentralized Economy. Washington, D.C.: The World Bank.

Wu, J. and Ma, G. (2012) Zhongguo Jingji Gaige Ershi Jiang [20 conversations on China's socioeconomic reforms] Beijing: Sanlian Shudian.

Wu, F. (2015) Planning for Growth: Urban and Regional Planning in China. New York: Routledge.

www.ce.cn (2015) Zhongguo chengxiang jumin shourubi 13 nian lai shouqi shuoxiao zhi 3 bei yixia [China's Urban-rural income disparity ratio goes under 3 for the first time in 13 years]. 20 January. Accessed on 13 March 2015 at: http://www.ce.cn/xwzx/gnsz/gdxw/201501/20/t20150120_4384230.shtml

Xinhua (2009) Zhongguo jishi: 1958 nian chengxiang eryuan huji zhidu queli [Remembering China: Urban rural dual structure hukou institution established in 1958]. 13 August.

Accessed on 11 May 2014 at: http://news.sina.com.cn/c/sd/2009-08-

13/165418428964.shtml

Xinhua (2014) Huanquan fabu: Zhongguo gongchandang dishibajie zhongyang weiyuanhui disanci quanti huiyi gongbao [Authorized release: Communique of the Third Plenum of the CPC Central Committee], 12 November. Accessed on 31 May 2014 at: http://news.xinhuanet.com/politics/2013-11/12/c_118113455.htm

$\mathrm{Xu}, \mathrm{C}$. (2011) The fundamental institutions of China's reforms and development. Journal of Economic Literature 49: 1076-1151.

Yang, J. (2012) Tombstone: The Great Chinese Famine, 1958-1962. [Transl. by Stacy Mosher and Guo Jian. Edited by Edward Friedman, Guo Jian and Stacy Mosher. New York: Farrar, Straus and Giroux.

Yang, R. and He, C. (2014). The productivity puzzle of Chinese exporters: Perspectives of local protection and spillover effects. Papers in Regional Science, 93(2): 367-384.

Young, A. (2000) "The Razor's Edge: Distortions and Incremental Reform in the People's Republic of China.” Quarterly Journal of Economics, 115(4):1091-1135.

Zhang, J. (2013). Marketization beyond neoliberalization: a neo-Polanyian perspective on China's transition to a market economy. Environment and Planning A, 45(7): 1605-1624.

Zhang, J. and Peck, J. (2014). Variegated Capitalism, Chinese Style: Regional Models, Multi-scalar Constructions. Regional Studies, (ahead-of-print), 1-27. DOI:

10.1080/00343404.2013.856514

Zhongguo Qingnianbao (2004) Difang baohuzhuyi yicheng quanguo tongyishichang de zuida zhangai [Local protectionism has become the biggest barrier to national economic unification]. 23 June.

Zhu, J. (2013) Zhonguo gaige de qilu [The crossroads of reforms in China]. Taipei: Linkingbooks. 
Zhu, R. (2011) Zhu Rongji jianghua shilu [Transcripts of Zhu Rongji's speeches]. Beijing: Renmin Chubanshe.

Zhu, Z. (2007). Reform without a theory: why does it work in China? Organization Studies, 28(10): 1503-1522. 


\section{Box 1 The fiscal origins and contemporary implications of bureaucratic entrepreneurialism}

$1949-$

1958

1980s

1994

Contemporary implications
- Following the founding of the PRC, a highly centralized fiscal system was instituted; provincial governments remitted their tax revenues to the central government and in turn received budgetary transfers. Direct taxation became relatively unimportant after the total nationalization of means of production in 1958; profits from SOEs became the major contributor to state revenues. Taxation was derived from commodities sold by SOEs, the primary 'market' was in the rural hinterland; this effectively meant rural residents, who already received very low wages to enable SOEs to make profits, were doubly-targeted by the state as sources of income. This was arguably worsened urban-rural disparities in income.

- One common form of taxation - income tax - was instituted in 1949 but implemented in practice only in the post-Mao era. In this sense, while the central government was nominally in political control over all provinces, in practice it was very dependent on the provinces' ability to generate profits through its SOEs. This created opportunities for local governments to define what constituted 'profits', and was arguably a key reason for local protectionism and the lack of economic integration between provinces. This in turn explains why marked variations in income and output were entrenched through the Mao era.

- This dependence would change following SOE reforms in the late 1980s, with the central government directly taking over the governance of some of the most important SOEs in the country (e.g. CNOOC, China Mobile and all of the top 5 banks).

- Fiscal reform introduced some degree of decentralization; provincial authorities had increased powers over the retention and allocation of resources. This decentralization process augmented the provinces' capacity for planning and developing their local economies.

- In tandem with the devolution of developmental power to local governments (right down to the village level) to control collectively-owned 'Township and Village Enterprises' (TVEs), local governments obtained further authority in the management of finance.

- However, problems began to emerge: the move left the central government short of funds, reduced its fiscal control over local authorities, and deepened uneven economic-geographical development. While uneven development was to become a driver of the CPC's 'open door policy' (i.e. integration into transnational circuits of capital flows), it swiftly became a blatant ideological contradiction.

- A tax-sharing scheme (fenshuizhi) was introduced to increase the center's share of total government revenue.

- 28 kinds of taxes were divided into three streams: one in which the central government enjoys full access, the other which flow directly to the subnational government, and one in which funds collected would be divided between the center and the localities.

- Under this scheme, value added tax (levied on goods and services and which is the single largest source of Chinese government revenue) was shared between the central government $(75 \%)$ and local governments (25\%).

- The 1994 reforms were credited with returning financial power (and hence developmental authority) from the local level to the central government, which in turn reinstated the central government's redistributive power

- Yet the redistributive process remains disjointed today (see, e.g. Shen et al, 2012): government agencies conduct redistributive programs independent from 
one another, and some of these programs contradict one another

- Redistribution is also not entirely egalitarian: part of the system involves redistributing taxes in the form of rebates to provinces that pay more taxes, and these provinces are almost always the richer coastal provinces. Ironically, this system creates the perverse scenario in which poorer provinces end up paying more net taxes (when rebates are subtracted) vis-à-vis the richer provinces. For this reason, the existing redistributive system is constitutive of uneven economicgeographical development.

- At the subnational level (particularly the sub-county scale), the reforms impelled local bureaucrats to be more 'entrepreneurial', as the reduction of revenues was not concomitant with the reduction of administrative responsibilities (e.g. maintenance of local roads, running of schools, etc.)

- This intensified the importance of "off-budgetary revenue", a Mao-era legacy: local governments sought extra-fees on services that are nominally illegal; borrow indirectly from banks or the so-called 'shadow banking system' (i.e. curbside lenders that fall outside the purview of the formal regulatory system); expand the leasing of public land, etc. According to statistics compiled by Pan and $\mathrm{Li}(2011)$, land-financed revenue constituted $65.9 \%$ of total local fiscal revenue in 2011 , a $70 \%$ increase from 2006.

- As variegations in off-budgetary revenue collection and expenditure engendered new waves of uneven development and increased risks of financial instability, the CPC introduced a new measure in September 2014 to rein in the powers of prefecture- and county-level governments to launch independent developmental projects. Officially termed 'The opinion on enhancing local governments' debt management", or 'document 43' in short, this injunction 'scaled up' matters related to infrastructural development to the central government and cut off the authority of these governments to attract investors directly. Debt-financing authority was also 'scaled up' to provincial governments, which made it more difficult for these local governments raise funds. How this measure correlates to the development of more 'rational' central-planning capacities requires future research.

Source: Author's compilation and analysis. 


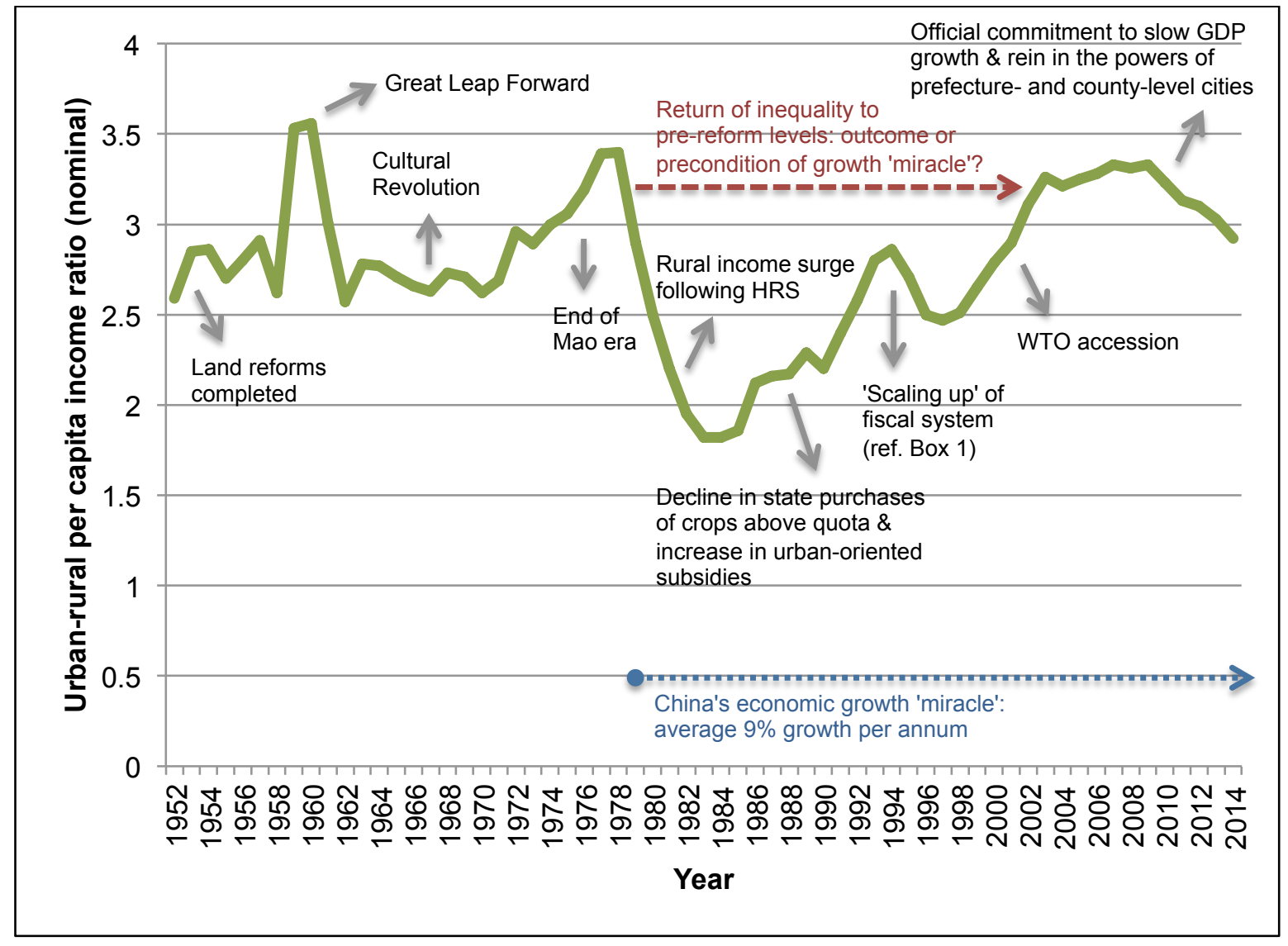

Figure 1 Nominal urban-rural income ratio (rural = 1), 1952-2014

Source: Data between 1952 and 1978 from Statistical Yearbook of China (1992); data between 1979 and 2012 from the National Bureau of Statistics (2012). 2013 and 2014 data from www.ce.cn (20 January 2015). Author's compilation, calculations and illustration. 
Table 1. Post-1949 Chinese politico-economic evolution as a complex palimpsest

\begin{tabular}{|c|c|c|c|c|}
\hline $\begin{array}{l}\text { Regulatory } \\
\text { layers }\end{array}$ & Spatio-temporal characteristics & Regulatory objectives & $\begin{array}{l}\text { Key capital } \\
\text { source }\end{array}$ & $\begin{array}{l}\text { Repurposed } \\
\text { institutions from } \\
\text { the Mao era }\end{array}$ \\
\hline $\begin{array}{l}\text { Recalibrating } \\
\text { uneven } \\
\text { development } \\
\text { (Mid-2000s to } \\
\text { present) }\end{array}$ & $\begin{array}{l}\text { - Takes place through simultaneous policy } \\
\text { experimentation in six institutionally-differentiated } \\
\text { 'nationally strategic new areas' at time of writing } \\
\text { (August 2015) } \\
\text { - Became apparent in the mid-2000s, as socio- } \\
\text { spatial disparities widened between provinces and } \\
\text { within city-regions } \\
\text { - Labor-intensive industries encouraged to move to } \\
\text { interior city-regions; coastal city-regions to } \\
\text { 'transform and upgrade' their positions in global } \\
\text { production networks (zhuanxing shengji) }\end{array}$ & $\begin{array}{l}\text { - Retain transnational } \\
\text { circulatory capital within } \\
\text { Chinese state spatiality } \\
\text { - Deepen integration with the } \\
\text { global financial system } \\
\text { - Capture cost advantages } \\
\text { of inland city-regions, } \\
\text { particularly access to low- } \\
\text { cost labor and land } \\
\text { - Unleash domestic demand } \\
\text { through rural-urban } \\
\text { migration }\end{array}$ & $\begin{array}{l}\text { - State-led fixed } \\
\text { capital } \\
\text { investments } \\
\text { (debt-financed) } \\
\text { - Expanded } \\
\text { domestic credit } \\
\text { creation } \\
\text { targeted at } \\
\text { consumers } \\
\text { - FDls }\end{array}$ & $\begin{array}{l}\text { - Hierarchical } \\
\text { regulation of state } \\
\text { spatiality through } \\
\text { the Lenin-styled } \\
\text { nomenklatura \& } \\
\text { informal patron- } \\
\text { client personnel } \\
\text { structure } \\
\text { - Quasi-cellular } \\
\text { economic } \\
\text { organization } \\
\text { remains, } \\
\text { characterized by }\end{array}$ \\
\hline $\begin{array}{l}\text { Urbanization } \\
\text { of capital and } \\
\text { labor power } \\
\text { (1980s to } \\
\text { present) }\end{array}$ & $\begin{array}{l}\text { - Originated from the } 1980 \text { launch of coastal Special } \\
\text { Economic Zones } \\
\text { - Distinct urban developmental bias became clear in } \\
\text { the early 1990s, as deepening rural privatization } \\
\text { and decollectivization of socioeconomic life created } \\
\text { pressures to absorb rural surplus labor } \\
\text { - Further entrenched urban-scale 'local state } \\
\text { corporatism' or bureaucratic capitalism (He \& Wu, } \\
\text { 2009; Wu, 2015) } \\
\text { - Central-local interaction began to shift from } \\
\text { provincial to major centers of real estate } \\
\text { development in leading city-regions (Tsing, 2010) }\end{array}$ & $\begin{array}{l}\text { - Increase overall economic } \\
\text { productivity } \\
\text { - Embed global production } \\
\text { networks } \\
\text { - Enhance competitiveness } \\
\text { of SOEs }\end{array}$ & $\begin{array}{l}\text { - FDls } \\
\text { - Tax credits } \\
\text { - State finance } \\
\text { - Private equity } \\
\text { financing } \\
\text { (through } \\
\text { domestic \& } \\
\text { foreign stock } \\
\text { exchanges) }\end{array}$ & $\begin{array}{l}\text { local economic } \\
\text { protectionism \& } \\
\text { inter-provincial } \\
\text { trade barriers } \\
\text { - Hukou institution } \\
\text { determines } \\
\text { control of labor } \\
\text { power flows } \\
\text { - Centralized } \\
\text { financial capital } \\
\text { controls, including } \\
\text { extensive state } \\
\text { participation in }\end{array}$ \\
\hline $\begin{array}{l}\text { Rural 'roll } \\
\text { back' } \\
\text { (1980s to } \\
\text { early } 2000 \text { s) }\end{array}$ & $\begin{array}{l}\text { - The precondition of China's economic 'miracle'; } \\
\text { occurred parallel to SEZ formation \& } 1984 \text { 'opening } \\
\text { up' of select coastal cities } \\
\text { - 'Household Responsibility System' (HRS) launched } \\
\text { in } 1980 \text { to select provinces (e.g. Anhui, Sichuan }\end{array}$ & $\begin{array}{l}\text { - Increase agricultural output } \\
\text { - Increase individual } \\
\text { incentive to farm } \\
\text { - Reduce state burden on } \\
\text { welfare provision }\end{array}$ & $\begin{array}{l}\text { - State } \\
\text { investments in } \\
\text { agricultural } \\
\text { infrastructure } \\
\text { - Domestic }\end{array}$ & $\begin{array}{l}\text { the domestic } \\
\text { financial system \& } \\
\text { commitment to } \\
\text { intervene, } \\
\text { whenever }\end{array}$ \\
\hline
\end{tabular}


and Guangdong) but established nationwide by

1984

- Decollectivization in 1984 triggered the rollback in social welfare provision in the vast rural hinterland where $80 \%$ of the national population resided in 1980

- Rural privatization continues to deepen through the 2000s, with large corporations increasingly

'crowding out' small producers (Webber, 2012)

National

politico-

economic

integration

$(1949-1978)$
- Economic space treated as a 'chessboard' by Chinese policymakers since the Mao-era (Zhao, 2009)

- People's Communes formed to universalize the formation of production units in the rural hinterland; heavy industrial units (danweis) concentrated in cities, supported by rural economic production

- Inter-unit interaction limited and controlled by the central government through mobility restrictions and trade barriers introduced on the premise of 'self-sufficiency'

- National economy became 'cellular', held together by a centrally-determined spatial hierarchy (Donnithorne, 1972; Ma, 2005)

\section{capital (private}

\&

SOEs/collective

s)

- Reproduce a Stalin-styled socialist economy capable of 'catching up with the UK and US'

- Reinforce the political power of the CPC over the newly-established national state space
- Aid \& favorable trade policies from the Soviet Union (up until 1960)

- Extraction of surplus value through 'price scissors' mode of accumulation "necessary", in

financial markets

"without

hesitation"

- State- and

collective

landownership

allows the central

state apparatus

total control over

the use- and

exchange-value

of land transfers

at the national

scale

- Centrallycontrolled SOEs dominate key economic sectors

- Industrial policy

remains a key

regulatory tool

Source: Author's compilation. 